\title{
Regenerating curriculum inquiry in Australia: some thoughts on this agenda
}

\author{
Lyn Yates \\ University of Melbourne, VIC, Australia, l.yates@unimelb.edu.au
}

\begin{abstract}
Bill Green introduced this issue of Point and Counterpoint with two excellent and challenging questions: 'is there a distinctively Australian curriculum scholarship?' and 'what counts as curriculum scholarship anyway?' The four contributions that follow are a stimulating introduction to the scope of what might be taken up in terms of answering such questions. Is it about being able to see and build a distinctive sense of curriculum inquiry as a theory or discipline or conceptual area of study (as Green's contribution)? Is it about considering the conditions which allow or constrain curriculum inquiry to be regenerated - either conditions of support for teachers and researchers in this area (e.g. resources, time) (Brennan), or conditions of visibility and structured foundations within formal university departments which would enable new scholars to take up this line of inquiry (O'Connor)? Is it about identity and definitional issues, about which scholarship is actually recognized or not recognized as curriculum inquiry, even when it is focused on an area that most would see as a curriculum area (Parkes, on History as a school-subject)?
\end{abstract}

Over thirty-five years ago I embarked on my own $\mathrm{PhD}$ on 'Curriculum Theory and NonSexist Education' (Yates 1987) and first encountered many of these issues. As Bill Pinar did some time later, I identified a number of important and different discourses of curriculum theorising making up the field, and I named these as (1) attempts to identify what is fundamental knowledge through an objective analysis of the nature of knowledge or of the educated person; (2) theorists who propose a culturally-located basis for curriculum; (3) theorists concerned with quality of content in the curriculum; (4) attempts to use the learner as the source of a quality curriculum experience (this is where I located the reconceptualist work of the 1970s); (5) the case for curriculum as social reproduction; and (6) approaching curriculum as a practical, pragmatic or 'democratic' activity. For each of these, I tried to investigate both what they added to curriculum thinking and what they were eliding or neglecting by that approach, and I did this both in general terms (how did they stack up as a theory or model?) but also, more specifically, in relation to the new challenges of the women's movement and questions about 'non-sexist education'. I look back on this time and my own starting points here to comment on three issues that I think are relevant to the questions Bill Green has set in train here: the situatedness of curriculum inquiry in both time and location; why does a regeneration of this particular field matter; and what is the scope and form of curriculum inquiry.

In the 1960s and 1970s there was a huge upsurge of activity around the world (in schools, in universities, in teachers' unions, in social movements and demonstrations) explicitly concerned with knowledge and curriculum, and four important curriculum journals (including Curriculum Perspectives) were founded. Curriculum Perspectives (opening editorial, October 1980) announced its intention to be a vehicle for a variety of perspectives on curriculum in a context where curriculum-making "has become recognized as a serious concern by many people in Australia, including teachers, advisory specialists, administrators and academics". On the question of a distinctively Australian form of inquiry, in my dissertation I noted snarkily about this Australian journal Curriculum Perspectives:

Of course, one would not wish to take this valuing of the indigenous rather than overseas authorities too far, and the lead article of the first volume was the product of 
a prominent overseas academic who happened to be visiting Australia, Paul Klohr. Foreign contributors continue to figure prominently in the journal: Klohr, Eisner, Pinar, Reid, Lawton, Maurice Holt, Giroux, Vallance have all given the Australian curriculum readership the benefit of their views, often as an adjunct to a brief visit to this country. (Yates, 1987, p. 398 - I left the gender composition of the contributors for discussion later!)

Here I was pointing to Australia's status as a peripheral rather than major nation-state, and some of the consequences that flow from this in terms of whose questions, originating in which contexts, we take up (see also Connell 2007). For example, I think some of the highly abstract nature of curriculum theorizing in the USA is a product of its dense graduate-school higher education structure whose imperative, in considerable part, is to produce theory. However I also noted in this review that one of the features of Australian curriculum scholarship that differentiated it from the then twin power centres of the UK and North America was that, unlike those countries, it attended to the literatures of both contexts. (Klohr, for example, referred to his stay in Australia as introducing him to "the curriculum literature of Australia and England, much of which I had been only dimly aware" [Klohr 1980, p. 5]). In other words, we should not automatically take conceptualisations arising from historical intellectual centres outside Australia as more authoritative and less constrained by their own settings than the work emerging in Australia (see also Yates 2016).

Another feature of the specifically Australian field of curriculum scholarship at that time, and perhaps subsequently, is who is involved and in what ways - teachers' unions in Australia then were strong sources of new curriculum thinking and conferences, and, as Brennan discusses, so too were dedicated curriculum branches in education departments - and many curriculum academics in universities moved into and out of policy and other action roles. Influential Australian curriculum scholars like Garth Boomer and Bill Hannan were grounded in particular working circumstances and networks that are different from those seen in the USA (where 'reconceptualism' itself is in part a response to curriculum being taken as the province of administrators and textbook publishers).

The 'situatedness' I was reflecting on in my dissertation then was both about big social movements and changes that were directing new energy to questions about knowledge and curriculum; and about the situatedness of Australia, and of the material and cultural conditions that those working on curriculum here drew on. The substance of both of these situations for curriculum inquiry in Australia have changed markedly since the time I was then writing about, but one important line of work for regeneration is to identify what questions and social movements matter now, and how the conditions in which Australian (and other countries') scholars operate and how who is part of the conversation continues to shape what is taken up.

In the 1980s there was no need to discuss why you wanted to undertake a dissertation on curriculum - very large numbers of such studies were being undertaken, even given the definitional problems noted by both O'Connor and Parkes. Since then, education faculties and research have moved away from this as a major locus of scholarship in education. Does this matter? Categorization and organizational structure are perennial problems in education faculties and in education journals, where almost all of the work can be labelled in a number of ways. Does it matter if I am seen as a gender or policy researcher, rather than a curriculum researcher, or if Bill Green or Robert Parkes are seen as scholars of English or History rather than of 'curriculum'? 
Some aspects of what has shifted may represent pragmatic choices (which labels now attract funding) or self-selection into some discourse communities rather than others. But there is a loss if certain kinds of questions go off the agenda, and if certain kinds of foundations and resources for thinking about and contributing to education begin to atrophy. O'Connor gives one example of this in her contribution: in universities, the spread of overarching templates of 'good teaching' by managements that fail to engage with different kinds of knowledge structures and purposes means curriculum (and knowledge) may be reshaped by policies that see themselves as not impinging on that area. Parkes also raises a perennially interesting issue about 'curriculum' scholarship: when is subject-specific study also curriculum inquiry? This matters, he shows, because it has implications for the kinds of literature and methodological approaches brought into play. And Green and Brennan point to other examples in the schooling arena: if 'curriculum' is simply left as what authorised bodies decide, rather than taken seriously as an arena of inquiry, then the creative and critical awareness of problems in those authorised frameworks, and broader thinking about renewal, will be weakened.

But, finally, what is 'curriculum scholarship'? In my perhaps nostalgically revisited dissertation I described this field not as a discipline or search to build or pin down a model or central concept, but rather as a 'discussion' or a 'conversation'. Disciplines in the Humanities and Social Sciences are not marked by paradigm consensus but by building an informed and enlightening perspective, and continuing to challenge and rethink that, to act back on the changing social world. For me (and this is where I part some ways with Green's particular argument for the conceptual in disciplinary terms), what is important is to keep in play different ways of thinking about curriculum, such as the six lines of work I outlined (but see also Green 2018 \& Yates 2018). I see curriculum inquiry as necessarily concerned both with bigger picture or more abstract thinking about knowledge, purposes, the person and with attention to the realities of practices and effects and possibilities in particular contexts at particular points of time that are bounded, not unlimited.

So I would not want us to turn to (or aspire to) one authoritative textbook model of what curriculum inquiry should look like, even if renewed. But I agree with the contributors here, that curriculum regeneration is important and that it requires not only a take-up by new generations of scholars, and the recognition of new kinds of questions, but also attention to prevailing conditions both in education faculties and in schools. This means, among other things, recognising and resourcing teachers and academics in ways that would allow a more extensive and systematic foundation for such crucial curriculum work.

\section{References}

Connell, R. (2007). Southern Theory: The Global Dynamics of Knowledge in Social Science. Sydney: Allen \& Unwin.

Green, B. (2018). Engaging Curriculum: Bridging the Curriculum Theory and English Education Divide, New York \& London: Routledge.

Klohr, P.R. (1980). “The Curriculum Field: Gritty and Ragged?”, Curriculum Perspectives, l(1), 1-7.

Yates, L. (1987). Curriculum Theory and Non-Sexist Education. Unpublished PhD dissertation, La Trobe University.

Yates, L. (2016). "Europe, Transnational Curriculum Movements and Comparative Curriculum Theorizing", European Education Research Journal, 15(3), 366-373.

Yates, L. (2018). "'Making' and 'Taking' Problems: The Curriculum Field and Michael Young”. In D. Guile, D. Lambert \& M. J. Reiss (Eds.), Sociology, Curriculum Studies and Professional Knowledge, (pp. 169-181). London: Routledge. 


\section{University Library}

\section{- M M N E R VA A gateway to Melbourne's research publications}

Minerva Access is the Institutional Repository of The University of Melbourne

Author/s:

Yates, L

Title:

Regenerating curriculum inquiry in Australia: some thoughts on this agenda

Date:

2018-04-01

Citation:

Yates, L. (2018). Regenerating curriculum inquiry in Australia: some thoughts on this agenda. Curriculum Perspectives, 38 (1), pp.85-87. https://doi.org/10.1007/ s41297-017-0039-1.

Persistent Link:

http://hdl.handle.net/11343/282763 